\title{
PERAN ELECTRONIC WORD OF MOUTH DALAM MEMBANGUN CITRA DESTINASI GUNA MEMPENGARUHI KEPUTUSAN BERKUNJUNG WISATAWAN KE SUATU DESTINASI PARIWISATA
}

\author{
Maftukhah Gustiani \\ Universitas Trunojoyo Madura
}

\begin{abstract}
This study aims to determine the role of electronic word of mouth in building a destination image to influence tourist decisions to a tourism destination. This research is a research. This research method is qualitative descriptive. Data collection methods used are through literature studies from several journals. The results of this study indicate that the better the electronic word of mouth, the more tourists will decide to visit a tourist destination. Electronic word of mouth communication is very influential on consumers who are interested in the advice of people who already have experience with tourist destinations which then create a brand image of a destination and decide to visit because of curiosity over the reviews he saw through social media. The better the electronic word of mouth, the better the image of a tourist destination. In other words, the impression of tourists on tourist destinations can arise after viewing posts or reading comments on social media accounts about tourist destinations.

Keywords: Tourism, Electronic Word of Mouth, Destination Image,Visit Decision
\end{abstract}

\section{PENDAHULUAN}

Teknologi dan informasi sekarang ini berkembang semakin pesat. Kini masyarakat semakin dimudahkan dengan aneka teknologi canggih. Efektivitas, efisiensi, dan kenyamanan teknologi telah mendapatkan tempat tersendiri di hati konsumen.Teknologi telah membuka akses bagi konsumen dalam mengakses beragam informasi. Konsumen dapat terhubung dengan berbagai sumber informasi yang berperan dalam proses keputusan pembelian dan pemenuhan kebutuhan. Berkembangnya internet memicu semakin kompleksnya informasi yang dibutuhkan oleh konsumen. Promosi dan iklanmenjadi kurang cukup dalam pemenuhan kebutuhan informasi.Sebelum internet berkembang, pendekatan antara produsen dan konsumen hanya sebatas komunikasi satu arah secara langsung, kini lebih menyentuh pada sisi emosional, membangun percakapan, dan menjadikan konsumen sebagai subjek yang sejajar.

Salah satu bukti berkembangnya teknologi informasi adalah maraknya media sosial dan penggunanya yang semakin meningkat setiap harinya. Media sosial berperan sebagai sarana komunikasi yang menghubungkan individu dengan individu atau kelompoklain, 
baik yang dikenal maupun tidak. Penelitian He, Zha and Li (2013) menunjukkan bahwa seseoarang menggunakan media sosial untuk menemukan teman baru, bersosialisasi dengan teman lama, mencari dan menerima informasi, dan menghibur dirisendiri.Seseorang dapat berbagi pengalaman terhadap penggunaan produk, melakukan review serta berinteraksi dengan pelanggan lainmelalui media sosial. Bentuk komunikasi seperti ini dikenal dengan sebutanword of mouth. Word of mouth saat ini telah mengalami pergereseran paradigma. Dulu komunikasi word of mouth dilakukan secara langsung dengan tatap muka dengan orang yang dikenal, namun saat iniword of mouth dapat dilakukan secara online dengan cakupan yang lebih luas, dalam hitungan detik apa yang kita bagikan dapat dibaca oleh jutaan orang lain. Seiring dengan pergeseran paradigma tersebut, word of mouth melalui media internet dikenal denganelectronic word of mouth.Sebagai versi Internet dari word of mouth, ulasan online, informasi baru yang disajikan dari perspektif konsumen yang telah membeli dan menggunakan produk, telah menjadi sumber informasi utama bagi konsumen. Ulasan online memiliki implikasi yang sangat penting untuk berbagai kegiatan manajemen, seperti membangun merek, akuisisi dan retensi pelanggan, pengembangan produk, serta jaminan kualitas. Perusahaan seperti Amazon.com dan Circuitcity.com, menyediakan akses yang mudah bagi pelanggan untuk membaca dan menulis ulasan untuk produk yang dijual di situs web mereka. Reichheld (2003) menyatakan bahwa kecenderungan pelanggan untuk merekomendasikan produk kepada orang lain -yang disebut nilai rujukan- adalah ukuran keberhasilan paling penting dalam bisnis saat ini. Reichheld berpendapat bahwa nilai rujukan memiliki korelasi yang lebih tinggi terhadap kinerja perusahaan daripada ukuran tradisional seperti pelanggan

Hennig - Thurau et. al., (2004), mengemukakan bahwa electronic word of mouth adalah pernyataan positif ataupun negatif yang dilakukan oleh pelanggan potensial ataupun mantan pelanggan tentang produk atau perusahaan, yang ditujukan untuk banyak orang atau lembaga via internet. Komunikasi electronic word of mouth yang terbentuk di sosial mediamemungkinkan penggunanya untuk saling berbagi informasi. Media sosial berkontribusi dalam penyampaian pesan-pesan pembangunan, termasuk di sektor pariwisata yang digunakan sebagai media promosi. Survei menyatakan sebanyak $87 \%$ pelancong menggunakan internet untuk merencanakan perjalanan wisata mereka dan sebanyak $40 \%$ dari wisatawan mengunjungi situs jejaring sosial untuk memilih tujuan 
liburan berdasarkan rekomendasi dari para pengguna media sosial (Toffeenet.com, 2015 dalam Nevit, 2016).

Lembaga Pooling Indonesia dan Asosiasi Penyelenggara Jasa Internet Indonesia (APJII) pada tahun 2016 melakukan survei terhadap pengguna internet dengan mengelompokkan perilaku pengguna internet atas dua, yakni berdasarkan konten komersial dan berdasarkan konten media sosial. Hasil survey tersebut menunjukkan bahwa konten komersial yang paling sering dikunjungi pengguna internet adalah web onlineshop sebesar 82,2 juta atau $62 \%$ pengguna, sedangkan untuk konten media sosial yang paling banyak dikujungi adalah Facebook sebesar 71,6 juta pengguna atau 54\% dan urutan kedua adalah Instagram sebesar 19,9 juta pengguna atau 15\%. Dari pemaparan data tersebut dapat disimpulkan bahwa mayoritas pengguna internet menggunakan internet untuk mengakses konten komersial dan media sosial berupa facebook dan instagram dalam kesehariannya. Selain itu kemampuan pengguna dalam mengakses media sosial tersebut menunjukkan bahwa mereka memiliki akun media sosial tersebut. Goldsmith dan Horowitz (2006) menyatakan bahwa penggunaan internet telah mengubah cara konsumen berkomunikasi dan berbagi pendapat atau ulasan mengenai produk atau jasa yang pernah dikonsumsi termasuk melalui media sosial instagram. Melalui media sosial instagram informasi tentang produk atau jasa lebih cepat diperoleh. Pengguna instagram cukup memasukkan kata kunci maka akan muncul konten dengan kategori yang dicari.

Traveling sebagai prioritas kedua orang Indonesia rupanya juga dipengaruhi oleh media sosial. Tak sedikit wisatawan yang mencari ide wisata lewat Facebook, Twitter, Instagram dan jejaring sosial lainnya. 65\% wisatawan mencari ide berwisata melalui pencarian sosial. 52\% Pengguna Facebook sangat dipengaruhi oleh foto-foto teman-teman dalam jaringan Facebook-nya untuk menentukan tempat wisata. 33\% Wisatawan mengubah rencana awal mereka setelah melihat foto-foto tersebut.Foto obyek wisata yang diunggah di instagram maupun media sosial dengan komentar dan ulasan yang baik akan memunculkan citra merek atas suatu destinasi wisata dan menarik minat user lain untuk datang berkunjung ke destinasi wisata tersebut.

Aaker (2013:203) menyatakan bawa merek dirasa mampu membantu perusahaan untuk erkompetisi dalam pasar produk dan jasa serta menunjukkan proposisi nilai dari strategi bisnis. Setiap konsumen memiliki perbedaan persepsi atas suatu merek. Perbedaan tersebut tergantung dari gambaran asosiasi merek yang ada dalam pikiran konsumen. 
Asosiasi merek dapat tercipta melalui pengalaman yang dirasakan secara langsung oleh konsumen dengan produk atau jasa terkait dan juga bisa melalui informasi yang diperoleh dari berbagai macam sumber. Gambaran atas asosiasi merek selanjutnya akan menghasilkan citra merek bagi konsumen. Merek selama ini telah diimplementasikan dalam strategi pemasaran produk dan jasa dimana industri pariwisata termasuk di dalamnya. Gagasan untuk memanfaatkan merek dalam strategi pemasaran destinasi pariwisata telah muncul pada tahun 1990-an (Morgan, et al., 2011:5). Begitu pula dengan citra merek. Pada bidang pariwisata, penelitian mengenai citra merek destinasi telah menjadi perhatian penting. Bigne, et al. (2001) mengemukakan bahwa citra destinasi dapat mempengaruhi proses pemilihan dan evaluasi wisatawan dalam menentukan minat berkunjung di waktu mendatang.

\section{TINJAUAN PUSTAKA}

\section{Wisatawan}

Undang-Undang Republik Indonesia Nomor 10 Tahun 2009 tentang Kepariwisataan Pasal 1 Ayat 3 menerangkan bahwa wisata merupakan kegiatan perjalanan yang dilakukan oleh seseorang atau sekelompok orang dengan berkunjung ke tempat tertentu dengan tujuan pengembangan pribadi, rekreasi, atau mempelajari keunikan daya tarik wisata yang dikunjungi dalam jangka waktu sementara. Undang-Undang tersebut menjelaskan pula bahwa pariwisata merupakan berbagai macam kegiatan wisata dan didukung berbagai fasilitas serta layanan yang disediakan oleh masyarakat, Pemerintah, Pemerintah Daerah dan pengusaha. Pariwisata berkaitan erat dengan wisatawan yang melakukan perjalanan di luar tempat tinggalnya untuk memenuhi kebutuhan sekundernya, seperti bersenang-senang, berbisnis, religi, mengunjungi teman/kerabat, dan lain-lain (Sunaryo,2013). Salah satu pembangunan Kepariwisataan Indonesia adalah destinasi pariwisata dengan kriteria pembangunan yang satu diantaranya yaitu memiliki citra yang sudah dikenal secara luas.

The International Union of Official travel Organization dalam Billy Castyana (2013) menggunakan batasan mengenai pengunjung secara umum, yaitu:

1. Wisatawan (Tourist) adalah seseorang atau kelompok yang melakukan suatu perjalanan wisata, jika lama tinggal sekurang-kurangnya 24 jam di daerah atau negara yang dikunjunginya. 
2. Pelancong (Excursionist) adalah seseorang atau kelompok orang yang melakukan suatu perjalanan wisata jika lama tinggal kurang dari 24 jam.

3. Traveler, yaitu orang yang melakukan perjalanan antar dua atau lebih lokalitas.

4. Visitor, yaitu orang yang melakukan perjalanan ke daerah yang bukan merupakan tempat tinggalnya, kurang dari 12 bulan dengan tujuan perjalanan bukan untuk terlibat dalam kegiatan untuk mencari nafkah, pendapatan, atau penghidupan di tempat $\mathrm{t}$ dengan tujuan perjalanan bukan untuk terlibat dalam kegiatan untuk mencari nafkah, pendapatan, atau penghidupan di tempat tujuan.

5. Tourism, yaitu bagian dari visitor yang menghabiskan wkatu paling tidak satu malam (24 jam) di daerah ynag dikunjungi.

\section{Pemasaran}

Pemasaran merupakan proses perusahaan menciptakan nilai bagi pelanggan dan membangun hubungan pelanggan yang kuat untuk menangkap nilai dari pelanggan sebagai balasannya (Amstrong and Kotler, 2009:6).

\section{Komunakasi Pemasaran}

Komunikasi pemasaran adalah sarana dimana perusahaan berusaha menginformasikan, membujuk dan mengingatkan konsumen baik secara langsung maupun tidak langsung mengenai produk dan merk yang dijual (Kotler dan Keller, 2009:172). Menurut Kotler dan Keller (2016:4) marketing communication mix terdiri dari delapan model utama komunikasi:

1. Advertising: bentuk presentasi nonpersonal yang berbayar dan promosi ide, barang, atau jasa oleh sponsor diidentifikasi melalui media cetak (koran dan majalah), media penyiaran (radio dan televisi), media jaringan (telepon, kabel, satelliite, wireless), media elektronik (rekaman suara, rekaman video, videodisk, CDROM, halaman web), dan media display (billboard, tanda-tanda, poster).

2. Sales promotion: berbagai insentif jangka pendek untuk mendorong percobaan atau pembelian produk atau jasa termasuk promosi konsumen (seperti sampel, kupon, dan premi), promosi perdagangan (seperti iklan dan tunjangan), dan bisnis serta tenaga penjualan promosi (kontes untuk agen penjualan). 
3. Events and experiences: kegiatan dan program yang disponsori perusahaan yang dirancang untuk menciptakan harian atau merek khusus terkait interaksi dengan konsumen, termasuk olah raga, kesenian, hiburan, dan menyebabkan acara seperti kurang formal.

4. Public relations and publicity: berbagai program internal langsung kepada karyawan dari perusahaan atau eksternal kepada konsumen, perusahaan lain, pemerintah, dan media untuk melindungi citra perusahaan atau produk.

5. Direct marketing: penggunaan email, telepon, fax, atau internet untuk berkomunikasi secara langsung dengan meminta respon atau dialog dari pelanggan tertentu dan prospek.

6. Interactive marketing: aktivitas online dan program-program yang dirancang untuk melibatkan pelanggan atau prospek secara langsung atau tidak langsung akan meningkatkan kesadaran, meningkatkan citra, atau menimbulkan penjualan produk dan jasa.

7. Word-of-mouth marketing: seseorang melakukan komunikasi baik lisan maupun tertulis pada orang lain, atau komunikasi elektronik yang berhubungan dengan manfaat atau pengalaman membeli atau menggunakan produk atau jasa.

8. Personal selling: interaksi tatap muka secara langsung dengan satu atau lebih calon pembeli untuk tujuan membuat presentasi, menjawab pertanyaan, danpengadaan pesanan.

\section{Electronic Word of Mouth}

Menurut Thurau et al., (2004) eWOM merupakan bentuk komunikasi pemasaran yang berisi tentang pernyataan positif atau negatif yang dilakukan konsumen potensial, maupun mantan konsumen tentang suatu produk, yang tersedia bagi orang banyak melalui media sosial internet. Konsumen cenderung menerima saran-saran dari kerabat, teman, dan kolega karena tingginya kredibilitas di antara mereka ketika membicarakan mengenai produk yang dikonsumsi. Word of Mouth Association (WOMMA) mendefinisikan secara sederhana mengenai word of mouth marketing sebagai tindakan seseorang dalam berbagi suatu informasi yang menarik kepada orang lain (womma.org: 2013). eWOM merupakan komunikasi pemasaran yang dilakukan secara online melalui media sosial internet (Schiffman dan Kanuk dalam Haekal, 2016: 27). Dari penjelasan di atas dapat ditarik 
kesimpulan bahwa $e$ WOM merupakan komunikasi pemasaran yang berbasis online melalui media sosial internet yang memiliki pesan berisi tentang pernyataan positif atau negatif yang dilakukan oleh konsumen potensial atau mantan konsumen. Dengan adanya Ewom komunikasi antara produsen dan konsumen menjadi lebih mudah, dan sesuai dengan kemajuan zaman saat ini.

\section{Citra Destinasi}

Citra atau image dapat diartikan sebagai persepsi masyarakat terhadap jati diri perusahaan atau asosiasi (Arafat, 2006:27). Sementara itu Lawson and Bovy (1997) dalam Lopes (2011) mendefinisikan bahwa "destination image is a concept as the expression of all objectives knowledge, prejudices, imagination and emotional thoughts of an individual or group about a particular location”, yang artinya adalah citra destinasi merupakan pengetahuan objektif, prasangka, imajinasi dan pikiran emosional individu maupun kelompok terhadap lokasi tertentu. Citra destinasi dalam kaitannya dengan penelitian ini merujuk pada teori citra merek, dimana merek tersebut dapat memberikan gambaran tentang suatu produk yang mana merek tersebut tidak dapat terlepas dari produknya yaitu destinasi wisata.

Citra merek dalam bidang pariwisata umumnya digeneralisasikan menjadi citra atas destinasi secara keseluruhan. Citra destinasi sendiri dapat didefinisikan sebagai sebuah kumpulan kepercayaan dan kesan terhadap destinasi berdasarkan informasi yang diproses dari berbagai macam sumber (Zang, et al. dalam Chiu, et al., 2016). Calon pengunjung akan lebih merasa tertarik mengunjungi destinasi dengan citra yang positif, sedangkan pengunjung yang telah berhasil merasa puas dengan citra positif tersebut memungkinkan untuk melakukan kunjungan ulang dan merekomendasikan destinasi ke calon pengunjung lain.

Citra (image) pariwisata menurut Pitana dan Diarta (2009) adalah kepercayaan yang dimiliki oleh wisatawan mengenai produk atau pelayanan yang wisatawan beli atau akan beli. Citra destinasi tidak selalu terbentuk dari pengalaman atau fakta, tetapi dapat dibentuk sehingga menjadi faktor motivasi atau pendorong yang kuat untuk melakukan perjalanan wisatawan ke suatu destinasi pariwisata. Schiffman dan Kanuk (2008: 135) menyebutkan terdapat tujuh faktor yang dapat membentuk citra merek meliputi kualitas 
atau mutu, dapat dipercaya atau diandalkan, kegunaan atau manfaat, pelayanan, resiko, harga, dan citra yang dimiliki oleh merek itu sendiri.

Citra destinasi berdasarkan penilaian wisatawan dapat berbeda-beda antara satu orang dengan orang lainnya. Coban (2012) dalam penelitiannya menjelaskan bahwa citra destinasi terdiri dari hasil penilaian rasional atau citra kognitif (cognitive image) dan penilaian emosional atau citra afektif (affective image) dari destinasi itu sendiri. Citra kognitif menurut Coban (2012) menjelaskan keyakinan dan informasi yang dimiliki seseorang mengenai suatu destinasi. Dimensi dari citra kognitif enam, yaitu atraksi wisata (touristy traditions), fasilitas dasar (basic facilities), atraksi budaya (cultural attractions), aksesibilitas dan substruktur pariwisata (touristy substructures and access), lingkungan alam (natural environment), dan faktor ekonomi (variety and economical factors). Sedangkan citra afektif menurut Artuğer et al. (2013) adalah gambaran emosi atau perasaan seseorang yaitu wisatawan mengenai suatu destinasi. Artuğer et al. (2013) membagi dimensi citra afektif menjadi tiga, yaitu kota yang hidup (lively city), kota yang membuat bersemangat (exciting city), dan kota yang menyenangkan (pleasant city).

\section{Keputusan Berkunjung}

Kunjungan wisata adalah istilah yang sering digunakan untuk orang yang berkunjung ke tempat wisata. Dalam dunia pemasaran kunjungan wisata bisa berarti sama dengan keputusan pembelian. Keputusan pembelian merupakan hal yang lazim dipertimbangkan konsumen dalam proses pemenuhan kebutuhan akan barang maupun jasa. Pada kebanyakan orang, perilaku pembelian konsumen seringkali diawali oleh banyaknya rangsangan (stimuli) dari luar dirinya, baik berupa rangsangan pemasaran maupun rangsangan dari lingkungan yang lain.

Menurut Kotler dan Armstrong (2008:181) Keputusan pembelian adalah membeli merek yang paling disukai dari berbagai alternatif yang ada. Proses pengambilan keputusan pembelian konsumen merupakan tahap yang penting dalam suatu keputusan. Menurut Kotler (2009:184) Proses keputusan pembelian merupakan proses psikologi dasar memainkan peranan penting dalam memahami bagaimana konsumen benar-benar membuat keputusan pembelian. Proses dalam keputusan pembelian ini memiliki lima tahap, yaitu pengenalan masalah, mencari masalah, evaluasi alternatif, keputusan pembelian dan keputusan pasca pembelian. 
Keputusan pembelian adalah pemilihan dari dua jenis atau lebih alternatif pilihan keputusan pembelian (Schiffman dan Kanuk, 2009:179). Keputusan pembelian adalah proses pengintegrasian yang mengkombinasikan pengetahuan untuk mengevaluasi dua atau lebih perilaku alternatif dan memilih salah satu diantaranya (Peter dan Olson, 2000:162). Swastha dan Handoko (2012: 102) menjelaskan bahwa keputusan pembelian yang diambil pembeli merupakan kumpulan dari sejumlah keputusan. Setiap keputusan pembelian mempunyai struktur sebanyak tujuh komponen, meliputi keputusan tentang jenis produk, keputusan tentang bentuk produk, keputusan tentang merek, keputusan tentang penjualan, keputusan tentang jumlah produk, keputusan tentang waktu pembelian, dan keputusan tentang cara pembelian.

\section{METODE PENELITIAN}

Penelitian ini memusatkan perhatian pada masalah aktual yang sedang berlangsung dan menjadi tren dikalangan pebisnis dan pengelola industri pariwisata yaitu peran electronic word of mouth dalam membangun citra destinasi guna mempengaruhi keputusan berkunjung wisatawan ke suatu destinasi pariwisata. Electronic word of mouth ini merupakan media promosi online yang memanfaatkan media sosial sebagai alat komunikasi sebagai penghubung antara pengguna yang satu dengan yang lain untuk saling memberikan rekomendasi suatu obyek wisata yang akan dikunjungi. Upaya penelitian ini adalah untuk menggambarkan suatu peristiwa atau gejala sosial yang terjadi sekarang ini secara natural, sehingga metode penelitian yang digunakan adalah diskriptif kualitatif, guna menganalisis peran electronic word of mouth dalam membangun citra destinasi guna mempengaruhi keputusan berkunjung wisatawan ke suatu destinasi pariwisata di era globalisasi ini, maka metode pengambilan data yang digunakan adalah melalui studi kepustakaandari beberapa jurnal.

\section{HASIL DAN PEMBAHASAN}

Ulasan literatur menunjukkan bahwa peran electronic word of mouth dalam membangun citra destinasi guna mempengaruhi keputusan berkunjung wisatawan ke suatu destinasi pariwisata perlu dilakukan oleh perusahaan khususnya yang bergerak di bidang industri pariwisata pada era globalisasi dengan persaingan yang semakin ketat ini. Electronic word of mouthmerupakan komunikasi pemasaran yang berbasis online melalui 
media sosial internet yang memiliki pesan berupa pernyataan positif atau negatif yang dilakukan oleh konsumen potensial atau mantan. Komunikasi ini berupa pemberian rekomendasi, informasi dan saran oleh pengguna sosial media setelah memakai suatu produk atau jasa. Saat ini media sosial merupakan media yang paling diminati dengan pengguna yang semakin hari semakin meningkat sehingga penggunaan media sosial menjadi alat yang efektif dalam mempromosikan suatu merek destinasi pariwisata. Karena wisatawan telah mendominasi dalam industri pariwisata, sangat penting bagi industri pariwisata untuk melihat proses yang menentukan pilihan tujuan dan persepsi wisatawan selama melakukan perjalanan wisatanya. Dengan pertumbuhan substansial dalam electronic word of mouth, ada kebutuhan bagi pemasar untuk lebih memahami bagaimana electronic word of mouth dapat mempengaruhi keputusan berkunjung wisatawan. Penelitian ini juga mengevaluasi efek moderasi dari keterlibatan citra merek pada hubungan antara electronic word of mouth dan keputusan berkunjung.

Hasil penelitian menunjukkan bahwa, pertama-tama, konsumen yang merasakan ketidakpastian terhadap suatu destinasi wisata cenderung mencari komentar online di media sosial. Melihat komentar online sangat membantu bagi konsumen karena dapat membuat konsumen merasa lebih percaya diri pada keputusan berkunjungnya. Komentar yang jelas, logis dan persuasif dengan alasan yang kuatberdasarkan fakta spesifik tentang destinasi wisata memiliki pengaruh positif terhadap keputusan berkunjung. Penelitian ini juga menemukan efek moderasi keterlibatan produk dan citra merek pada hubungan antara electronic word of mouth dan keputusan berkunjung.

Studi ini memberikan beberapa kontribusi praktis. Hasil utama menekankan pentingnya mengelola tinjauan wisatawan secara online dengan benar. Karena fungsi word of mouth online baik sebagai informan maupun rekomendasi dapat digunakan secara strategis sebagai saluran komunikasi. Misalnya, industri pariwisata dapat memberikan format ulasan yang memungkinkan pengulas untuk memposting ulasan berkualitas tinggi yang berfokus pada peran informan dari ulasan online wisatawan (menyediakan informasi yang berorientasi pada pengguna untuk meningkatkan pemahaman wisatawan terhadap destinasi pariwisata). Selanjutnya, penelitian ini membawa beberapa wawasan baru bagi perusahaan untuk menggunakan electronic word of mouth sebagai bagian dari kampanye pemasaran strategis mereka dalam mempengaruhi keputusan berkunjung untuk wisatawan baru dan wisatawan yang telah berkunjung untuk melakukan kunjungan ulang. Namun, 
disamping mempengaruhi keputusan berkunjung, perusahaan juga harus memanfaatkan electronic word of mouthdalam menciptakan citra destinasi yang positif untuk memperkuat keputusan wisatawan melakukan kunjungannya.

Berdasarkan hasil penelitian ini, kebiasaan wisatawan pada generasi millennial saat ini yang melakukan kunjungan ke suatu destinasi hanya untuk berbagi momen di sosial media melalui foto ataupun video, para wisatawan ini masih mempertimbangkan faktor citra merek destinasi wisata itu sendiri dalam menentukan keputusan kunjungannya. Berdasarkan hal itu, dapat disimpulkan bahwa wisatawan dalam hal ini akan memutuskan untuk berkunjung jika citra merek destinasi tercipta secara positif dalam pikiran mereka. Citra merek destinasi yang positif dan sesuai harapan pengunjung akan mendorong wisatawan melakukan kunjungan. Keputusan pengunjung dalam melakukan kunjungan pada detinasi wisatanyatanya tidak hanya timbul dari hasil foto atau video yang berhasil diambil pada destinasi yang mereka kunjungi untuk kepentingan media sosial masingmasing melainkan juga timbul dari adanya citra merek destinasi yang positif. Menurut staf khusus Kementrian Pariwisata, Judi Rifajantoro, generasi millennial memiliki kebiasaan untuk menunjukkan eksistensi melalui sosial media terutama di Instagram dengan feeds yang diatur sedemikian rupa sehingga terlihat menarik (kumparan.com). Kebiasaan tersebut akan membuat wisatawan lainmerasa ingin berkunjung ke destinasi yang berbedabeda dan merasa cukup ketika destinasi tersebut telah eksis di media sosial mereka masingmasing. Sehingga komunikasi electronic word of mouth ini sangat berpengaruh terhadap konsumen yang tertarik dengan saran dari orang yang telah memiliki pengalaman terhadap destinasi wisata sehingga akan memunculkan citra merek suatu destinasi dan mempengaruhi keputusan untuk berkunjung karena rasa penasaran atas ulasan yang dilihatnya melalui media sosial. Semakin baik electronic word of mouth maka semakin meningkat citra suatu destinasi wisata. Dengan kata lain, kesan wisatawan terhadap destinasi wisata dapat timbul setelah melihat posting maupun membaca komentar yang ada pada akun media sosial tentang destinasi wisata.Hal ini sejalan dengan pendapat yang diungkapkan Kotler (2000) bahwa setiap pelanggan memiliki kesan tertentu terhadap suatu merek, yang timbul setelah melihat, mendengar, membaca atau merasakan merek produk, baik melalui TV, radio, maupun media cetak. Kemudian semakin baik electronic word of mouth maka semakin meningkat pula wisatawan yang memutuskan untuk melakukan kunjungan pada suatu destinasi wisata sehingga dengan adanya komunikasi electronic 
word of mouth yang terjadi di media sosial menjadi dorongan atau rangsangan internal yang kuat dalam memotivasi followers akun media sosialuntuk melakukan tindakan, dimana dorongan ini dipengaruhi oleh stimulus berupa sharing informasi antar pengguna maupun posting destinasi wisata dariakun tersebut.

\section{Rekomendasi Dan Keterbatasan Penelitian}

Rekomendasi yang berasal dari studi penelitian ini melibatkan replikasi dari studi dan penelitian berkelanjutan tentang electronic word of mouth dan citra destinasi dalam meningkatkan pertumbuhan dan perkembangan industri pariwisata. Kemudian pihak pengelola wisata hendaknya membuat akun media sosial sendiri untuk destinasi wisatanya dikarenakan sebagian besar wisatawan melakukan pencarian informasi terkait tempat wisata yang akan dikunjungi sehinga memudahkan wisatawan memperoleh informasi dan mengetahui lebih mendetail tentang suatu destinasi pariwisata sebelum memutuskan untuk berkunjung. Hal ini dikarenakan faktor utama yang mempengaruhi electronic word of mouth terhadap keputusan berkunjung adalah pencarian informasi. Perusahaan juga harus menciptakan hubungan yang baik dengan followers untuk memberikan ikatan emosional antara wisatawan dan pemilik akun destinasi wisata dengan membalas atau menanggapi review yang dilakukan wisatawan. Selain itu pemilik akun perlu mengunggah foto, video atau melakukan kontes fotografi secara rutin dalam menarik keterlibatan wisatawan untuk ikut memasarkan destinasi wisata. Perusahaan juga harus mempertahankan faktor-faktor yang mempengaruhi terhadap keputusan berkunung pada suatu destinasi wisata untuk meningkatkan intensitas kunjungan wisatawan.

Keterbatasan dari penelitian ini berupa tidak adanya peneltian secara langsung pada obyek wisata sehingga diharapkan bagi peneliti selanjutnya dapat membahas lebih mendetail lagi mengenai suatu destinasi wisata dengan penelitian langsung pada objek menggunakan analisis kualitatif atau kuantitatif. Kurangnya objek penelitian, ruang lingkup yang lebih luas dan sampel yang diteliti juga menjadi keterbatasan dalam penelitian ini sehingga penelitian selanjutnya diharapkan dapat memperluas objek penelitian pada destinasi wisatayang ada di Indonesia, serta penggunaan sampel yang lebih banyak agar dapat memberikan hasil yang lebih spesifik dan mungkin hasil penelitian yang didapat bisa berbeda. Penelitian selanjutnya juga diharapkan dapat menambahkan variabel 
lain seperti brand awarness atau kesadaran destinasi sehingga nantinya dapat diketahui tingkatan followers akun destinasi wisata dalam mengenali merek pariwiata Indonesia.

\section{KESIMPULAN DAN SARAN}

Terlepas dari keterbatasan dan proposisi untuk penelitian selanjutnya, penelitian ini membahas pertimbangan yang signifikan. Penelitian ini menemukan dampakelectronic word of mouth dalam membangun citra destinasi yang selanjutnya akan mempengaruhi keputusan berkunjung wisatawan ke suatu destinasi wisata. Teoritis telah mengungkapkan bahwa sektor bisnis harus menilai pentingnya penerapan electronic word of mouth sebagai media promosi online dan melihat potensi manfaat.electronic word of mouth merupakanbentuk komunikasi pemasaran yang berisi tentang pernyataan positif atau negatif yang dilakukan konsumen potensial, maupun mantan konsumen tentang suatu produk, yang tersedia bagi orang banyak melalui media sosial internet. Meskipun komunikasi word of mouth tradisional dianggap efektif bagi sebagian orang. Namunkomunikasi ini hanya bisa dilakukan dengan bertatap muka secara langsung sehingga cakupan informasi yang disebarkan tidak begitu meluas. Selain itu adanya media sosial sebagai alat komunikasi menjadikan orang-orang malas untuk keluar mencari informasi dan lebih memilih melakukan pencarian informasi dan rekomendasi secara online. Rekomendasi, saran dan ulasan pengalaman yang dibagikan wisatawan melalui sosial media tentang suatu destinasi wisata akan menarik pengguna lain untuk ikut berkomentar memberikan review-nya. Pemberian rekomendasi yang positif akan memunculkan citra merek suatu destinasi dan wisatawan akan memutuskan untuk melakukan perjalanan wisata karena rasa penasaran atas ulasan yang dilihatnya.

\section{DAFTAR PUSTAKA}

Sari, Fungkiya dan Pangestuti,Edriana. 2018. Pengaruh Electronic Word Of Mouth (EWom) Terhadap MinatBerkunjung dan Keputusan Berkunjung: Studi Pada Wisata Coban Rais kph Pujon. Jurnal Administrasi Bisnis. Vol. 54 No. (1)

Isnaini, Putri Rizkiah dan Abdillah, Yusri. 2018. Pengaruh Citra Merek Destinasi Terhadap KeputusanBerkunjung Dan Kepuasan Pengunjung serta Dampaknya padaMinat Kunjung Ulang: Survei pada Pengunjung Taman Rekreasi Selecta Kota Batu yang Termasuk DalamKategori Generasi Millennial. Jurnal Administrasi Bisnis. Vol. 55 No. (2) 
Putra, dkk.Pengaruh Citra Perusahaan terhadap Minat Berkunjung dan Keputusan Berkunjung: Survei pada Pengunjung Taman Rekreasi Pt.Selecta, Kota Batu, Jawa Timur. Jurnal Administrasi Bisnis. Vol. 26 No. (2)

Sari, dkk. 2017. Pengaruh Electronic Word of Mouth terhadapKeputusan Pembelian pada Toko OnlineBukalapak.com. Jurnal Manajemen Magister. Vol. 03. No. (1)

Ekawati, dkk. 2014. Pengaruh Electronic Word of Mouth terhadap Pengetahuan Konsumenserta Dampaknya pada Keputusan Pembelian: Survei pada Followers Account Twitter @WRPdiet. Jurnal Administrasi Bisnis. Vol. 14 No. (2)

Hasan, Ali dan Setiyaningtiyas, Niken Widiati. 2015. Pengaruh Electronic Word of Mouth pada Media Sosial Facebook terhadap Keputusan Berkunjung ke Desa Wisata Nglanggeran Gunungkidul. Jurnal Media Wisata. Vol. 13. No. (1)

Mulyati, Dkk. 2018. Pengaruh Electronic Word of Mouth terhadap Citra Destinasi serta Dampaknya pada Minat dan Keputusan Berkunjung Wisatawan Domestik pada Destinasi Wisata Kota Bukittinggi.Jurnal Ekonomi \& Bisnis Dharma Andalas. Vol. 20 No.(1)

Suwarduki, dkk. 2016. Pengaruh Electronic Word of Mouth terhadap Citra Destinasi serta Dampaknya pada Minat Dan Keputusan Berkunjung: Survei pada Followers Aktif Akun Instagram Indtravel yang telah Mengunjungi Destinasi Wisata di Indonesia. Jurnal Administrasi Bisnis. Vol. 37 No. (2)

Hanif, dkk. 2016.Pengaruh Citra Destinasi terhadap Kepuasan Wisatawan serta Dampaknya terhadap Loyalitas Wisatawan: Studi pada Wisatawan Nusantara yang Berkunjung ke Kota Batu. Jurnal Administrasi Bisnis. Vol. 38 No. (1)

Lin, et al,. 2013. Electronic Word-of-Mouth: The Moderating Roles of Product Involvement and Brand Image Technology Innovation and Industrial Managemen, Phuket, Thailand

Chiu, et al,. 2016.The influence of destination image andtourist satisfaction on tourist loyalty:a case study of Chinese tourists in Korea. International Journal of Culture, Tourism and Hospitality Research. Vol. 10 No. (2)

Thurau, et al,. 2004. Electronic Word of Mouth: Motives for and Consequences of Reading customerArticulations on the Internet. Journal of Interactive Marketing. Vol. 18. No. (1) 

